\title{
Reflection Of The Use Of Intranet To Improve The Performance Of Electronic Governance An Exploratory Study Of The Ministry Of Higher Education And Al-Karkh Education Directorate
}

\author{
Hussein Hamed Khudair Jinah ${ }^{1}$, Duha Khalid Abdul-Rahman Al-Malah ${ }^{2}$ Raed Sami Sarhan $^{3}$ \\ General Directorate of Education in Baghdad, The third Al-Karkh Governorate, Baghdad, Iraq ${ }^{1,3}$ \\ Northern Technical University, Mosul, Iraq ${ }^{2}$ \\ Corresponding Authorduhakm@ntu.edu.iq
}

Article History:Received:11 January 2021; Accepted: 27 February 2021; Published online: 5 April 2021

\begin{abstract}
The presence of a strong internal guaranteed and secure intranet with good specifications is the important factor in improving the performance of the institution and establishing a good system to start work with electronic governance, a basic and supportive indicator to strengthen comprehensive audit and optimization of available resources practiced by boards of directors or organizations according to the style and style of the institution chosen to run its affairs when preparing an organization with a secure and discreet internet network with global specifications, equipped with efficient and reliable information and communication systems that reassure the network users of relying on them to walk their administrative affairs and raise the level of the organization's performance by facing the risks that prevent the achievement of the objectives of the Organization. The internal network framework is also considered to provide all the requirements, electronic devices, modern communication equipment with high-quality technology and a practical and programmatic design that reduces the burden of administrative costs and strengthens the internal administrative system with its control auditing and reformative software systems with the ability to accelerate the completion of the work and archive it electronically and lack of storage and provide space and reducing space its size. In this study, the researchers discussed the necessity of employing the internal internet for the sustainability and stability of the management system for its institutional resources in order to reach its goals in the best ways, time and costs, and electronic governance that seeks to continuously adapt to the work environment and adapt to the challenges of the current era by programming the work of the departments and administrative divisions.

Keywords-Internet, Electronic Governance, Transparency, Control, Data generation

Recently, interest in the issue of governance has emerged, as the departments of organizations and others have reached the importance of the topic for the benefits it brings to today's organizations. Organizations have sought to increase awareness of the authority's responsible parties for institutions in economic, environmental, and legal terms, so governance has emerged having rational leadership of the institution's resources for access to its goals in the best way, minimal effort, time and costs. Governance focuses on the main principles of the institution's work, which are participation, transparency, accountability and the close relationship between them. In addition to the institutionalization, professionalize and globalization of practices and activities in light of corporate ethics, [1,2,3]so that the activities and practices of the institution to be legal, professional, ethical and global. The study confirms the spaces and places for the establishment of an internal intranet network linking the units, departments and sections of the institution in a planned, studied and equipped way with a number of computers, and the service device, network installation equipment, and network operating programs. In addition to programming the work of these units, divisions, and departments electronically, and building a database that includes all the information and data of human resources $[4,5,6]$.
\end{abstract}

1. Introduction: -

2. Methodology

2.1. Problem of the study

The ministries of (Education) generally suffer from a problem which is (how to improve the performance of electronic governance, using the Intranet).

2.2. Aims of the study

The study aims at the issue of designing the internal internet network with a focus on its physical quality as the availability of high-specification communication devices, equipment with supporting programs and systems that are the basis for building a governing administrative system has the ability to face difficulties and obstacles to manage its resources. The study contains a practical model that takes into consideration all the factors affecting the management process electronically with its descriptive analytical and analytical approach by analyzing the dimensions of the networks and communications issue and describing the elements of distinct success in this field. 


\subsection{Importance of the study}

1- The study has great importance in the theoretical part, as it provides an applied study that can be used in the labor market, which researchers did not address previously.

2- Its importance comes from providing all service capabilities for the use of electronic devices and equipment, information and communication technology which contribute to the enrichment of the controlling, auditing and administrative processes and how to maintain its viability.

3- Education institutions at the local level can be seen in the near future as "institutions that create decision-makers", meaning that they contribute to establishing "e-governance societies" in a fundamental way and building new ways of thinking.

4- Government institutions develop legislation in line with e-governance.

\subsection{The hypothetical design of the study:}

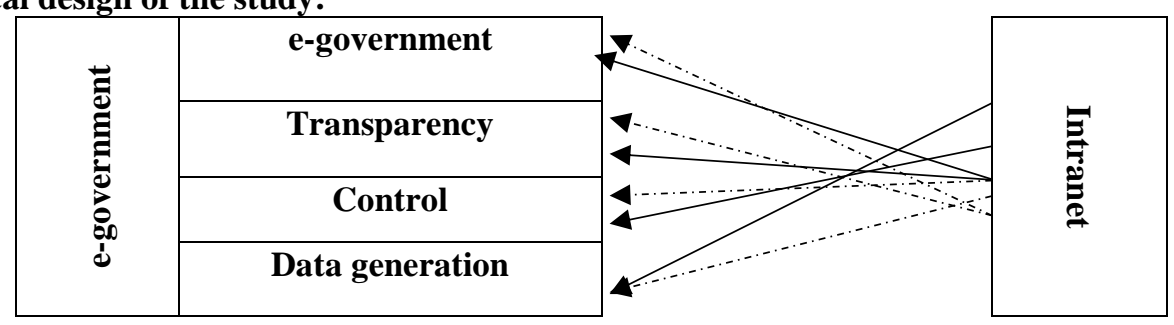

\subsection{Hypothesis of the study}

The hypotheses are guesses that require verification of their validity and are formulated based on the hypothetical study model, so the hypotheses are as follows:

The first main hypothesis is (there is a significant correlation between the use of the intranet and improving the performance of electronic governance), so the derive sub-hypotheses are derived from it:

1- There is a significant correlation between the use of the Intranet and electronic governance.

2- There is a significant correlation between the use of the intranet and transparency.

3- There is a significant correlation between the use of the Intranet and the generation of data.

4- There is a significant correlation between the use of the Intranet and control.

The second main hypothesis is (there is a significant effect of using the Intranet in e-Governance) and the following hypotheses emerge from it:

1- There is a important effect of using the intranet network in electronic governance.

2- There is a important effect of using the intranet on transparency.

3- There is a important effect of using the intranet on data generation.

4- There is a important effect of using the intranet on supervision.

\subsection{Methodology of the study}

The current study relied on the descriptive and analytical approach in order to achieve the goals of the study and answer questions and choose hypotheses through the theoretical and practical parts of study in order to enable compatibility between these two parts by study and analysis. Subjects of the study was chosen to test the variables and the hypothetical model in accordance with the sound scientific foundations of the field of study, in order to achieve the goals and directions of the study, so the Northern Technical University and the Al-Karkh Education Directorate were chosen. (75) questionnaire form was distributed, and 74 valid questionnaires were retrieved. And the intranet network was used with e-governance, so the e-governance were variables like e-governance, transparency, data generation, and control. The researchers adopted methods of collecting primary and secondary data to complete the study, both theoretically and practically, as the secondary data were drawn from sources related to the variables of the study to establish theoretical frameworks. As for the field side, the primary data axis, which was collected through the questionnaire, represented the intranet data, either. The focus of e-governance has been e-governance, transparency, data generation, and oversight.

\section{Theoretical framework}

It is link two or more devices together for exchange of the information. Whether this device is a personal computer or a central computer in addition to what is known as ports or terminals, terminals and other specialized devices such as printers and input and output channels. In addition to the software packages responsible for managing devices and operations that take place within the network. The computer network is based on this basis the process of transferring 


\section{Reflection Of The Use Of Intranet To Improve The Performance Of Electronic Governance An Exploratory Study Of The Ministry Of Higher Education And Al-Karkh Education Directorate}

data, information and messages between those computers connected to the network or any other networks connected to that network $[7,8]$. The computer network also defines that it is two computers or a group of devices connected with each other by means of connection wires or cables, and it can also be connected wirelessly also to exchange data and files between them, and of course it is not a condition that the networks are composed of computers, they are It includes all types of devices that can communicate with a computer such as printers, telephones, and surveillance cameras as well [9,10]. Finally, it is a computer network connected to millions of computers worldwide. With a server that stores and sends web pages and emails [11]. A local area network (LAN) is a group of computers and other devices that are connected to each other via a network, and they are all located in the same location, usually within one building such as the office, communicating with each other and they are confined to one building [12].

\section{1- Computer:}

It is an electronic electrical device that has been programmed to enter data, process it, store it and retrieve it at another time and show it to the user whenever requested, and it can also transfer data to another computer or group of computers by connecting it with a computer network and the following figure shows the basic operations of the computer's work [13] .

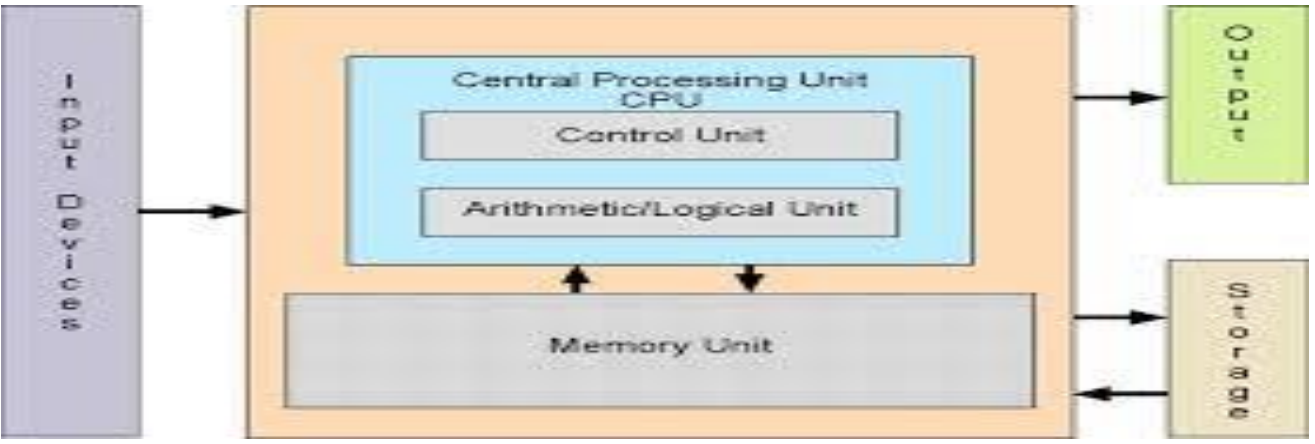

Figure 1. shows the basic operations of computer work

\section{2- router:}

It is a device used in computer networks to direct data packets between them, where the router controls the movement of data in the intranet. Packets of data in a network are transferred from one router to another router, from its source, until it reaches the intended destination [14].

\section{3- Switch:}

It is a device used to direct information from the point of ask to the required receiving point where the switcher has a prior knowledge of (MAC address) of devices connected to the intranet, which leads to improving the performance of the intranet and maintaining the speed of data transmission without any delay [15].

\section{4- Connecting Cords:}

It is a copper wire consisting of four twisted and sheathed pairs which are usually armored to increase their protection, working to connect computers with each other to form a network [16].

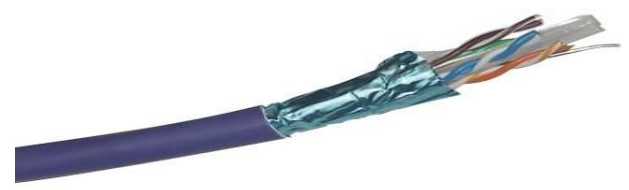

The concept of governance:

Figure 2. shows the connection cable

Governance is one of the modern management concepts used to achieve quality and excellence in performance as it was used in the financial and financial aspects and refers to the laws and standards that define the relationship between the management of the organization and all that is related to it to ensure that the administration exploits financial and material resources and achieve effective control [17].

It is also known as the rational leadership of the economy in general, those governing procedures and management practices for good power, which would strike a balance in the rights of opposing interests [18].

Fifth: The concept of electronic governance: 
- The long-term strategic direction of key elements in the organization and adapting its activities with the environment and the available electronically resources in order to reduce threats and maximize available opportunities [19].

- It is the set of instructions and software commands that are used to build a database containing patterns and decisions that direct the organization's activities electronically using the network [20].

Procedural definition: A good understanding of modern technological changes, including their networks, communications and applications that contribute to enhancing the capacity for sustainability and achieving the future vision within the wise leadership of that organization.

\section{The importance of electronic governance:}

The current smart society proposes the beginning of the post-information society, on the need to rely on communication networks to build a technological community that makes people's lives more convenient and efficient, as e-governance is an application of information and communication technology (ICT) to provide government services, and facilitate the exchange of information between different stakeholders, The importance of e-governance lies in saving time due to providing services through a single window, activating procedures and better management of offices and records, reducing corruption and improving attitude and behavior, and the ability to deal[21]. The importance of electronic governance is that it is a strategic goal for modernizing management, which is clearly reflected in management reforms, as traditional services do not meet the demands of customers and are ineffective, as the importance of technology appeared in providing innovations to overcome inefficiency and to achieve optimal governance results, and provide new interactive opportunities In a transparent and clear manner in the decision-making process by organizations management $[22,23]$.

\section{Electronic Governance Dimensions: 1- Electronic Governance:}

There are many characteristics that represent e-governance, which have been pointed out by many books and researchers in the field of governance are represented by (discipline, transparency, issue, responsibility, justice, information and data generation, control), Therefore, the e-governance variables were chosen by the two researchers that benefit the study (e-governance, transparency, data generation, and control) as dimensions of the study of e-governance [24].

\section{2- Transparency:}

This dimension is considered one of the most important dimensions of achieving or implementing the e-governance system, through the availability of all information accurately and clearly, and not to hide any information and show it to the public dealing with it in a timely manner, as well as the disclosure of all data and other information, and performance reports and the method of using powers. Transparency means paying attention to the salaries and benefits granted to general managers and their ranks, the expected risks in the business, accurate classified financial statements, material issues related to employees, and approved governance structures and policies [25].

\section{3- Data generation:}

Generating data is obtaining it in a timely manner, and accurate information enables stakeholders to make policies informative, and take action when goals and standards are not met, as the information is relevant to all decision makers throughout the organization, at the level of policies, programs and administration [26].

\section{4- Control:}

Control is one of the dimensions on which electronic governance is based in the organization, as it includes the formal setting of goals, performance measurement and feedback, and it is one of the methods that enables management to evaluate the strategies it follows. The aim of oversight is to demonstrate the importance of a sound and tight system in the organization that ensures it achieves its vision, mission and goals effectively and uses its resources efficiently[27].

\section{4. $\quad$ Practical framework}

The results of the researcher were reviewed in this study, as they were interpreted and discussed in a way that suits the goals of the study. The results of the questionnaire were presented as the comparison between two axes, first axes are the internet and the second axes are e- governance, whose dimensions were represented by (e- governance, transparency, data generation, control). Explaining which of them was the best in terms of the relative, importance of dimensions and axes and the correlation relationships between axes and dimensions and indicating the amount of influence of the intranet axis on the axis of electronic governance, so the researcher followed the descriptive statistical analysis method in analyzing the results of the questionnaire will be presented as the arithmetic mean and standard deviation of each dimensions for each dimensions of axis. 


\subsection{Statistical indicators:}

The researcher relied in the statistical analysis on the data and information obtained from the research according to Likert's quintile scale, and the researcher used the most important statistical indicators to suit the hypotheses of the research and its questions, which are as follows:

$\checkmark$ Repetitions and percentages: to know the number and percentage of respondents within the research sample.

$\checkmark$ Weighted Arithmetic Medium: It is used to know the degree of approval of the surveyed sample for questions.

$\checkmark$ The truthfulness and consistency of the questionnaire: the extent of the consistency of the questionnaire paragraphs is measured by it.

$\checkmark$ Standard deviation: It is used to find out the extent of dispersal of the sample responses for the degree of approval.

$\checkmark$ Correlation coefficient Person: It is used to measure the extent of correlation of the research variables with each other and to determine the type of relationship is it positive (positive) or inverse (negative).

$\checkmark$ Test F: It is used to find the effect of the independent variables in the research on the adopted variable.

$\checkmark$ Simple regression equation: It is used to know the extent of the independent variable's influence on the dependent variable.

Note The moral value (sig.) Was adopted in testing the research hypotheses instead of the tabular values due to the accuracy of the calculated results from the moral value (sig.), It is worth noting here that all these indicators have been calculated by the statistical package for quality of service sciences program (SPSSV21).

4.2. The demographic variables of the study: It shows the description of the demographic variables for the study sample individuals.

Table 1. Repetitions and percentages of the demographic variables for the study

\begin{tabular}{|c|c|c|c|}
\hline \multicolumn{4}{|c|}{ Years of service } \\
\hline \multirow{8}{*}{ Valid } & & Duplicates & \%Percentage \\
\hline & $5-1$ & 7 & 9.45 \\
\hline & $10-6$ & 14 & 18.91 \\
\hline & 15-11 & 16 & 21.62 \\
\hline & $20-16$ & 18 & 24.35 \\
\hline & $25-21$ & 6 & 8.1 \\
\hline & More than 25 & 13 & 17.57 \\
\hline & Total & 74 & 100.0 \\
\hline \multicolumn{4}{|c|}{ Age } \\
\hline \multirow[t]{6}{*}{ Valid } & Less 25 & 2 & 2.7 \\
\hline & $34-25$ & 7 & 9.45 \\
\hline & 44-35 & 23 & 31.08 \\
\hline & $54-45$ & 20 & 27.1 \\
\hline & 55 More & 22 & 29.71 \\
\hline & Total & 74 & $\% 100$ \\
\hline \multicolumn{4}{|c|}{ Sex } \\
\hline \multirow[t]{3}{*}{ Valid } & Mal & 39 & 52.7 \\
\hline & Female & 35 & 47.3 \\
\hline & Total & 74 & 100.0 \\
\hline
\end{tabular}

We note in Table (1) the following:

With regard to the gender variable, the frequency of males was the highest, reaching 39 by $52.7 \%$, while the frequency of females 35 was $47.3 \%$. also, with regard to age groups, so that the frequency of the age group, which ranged between 35 and 44 with the highest frequency, was $31.08 \%$. and finally with regard to the number of years of experience, the highest frequency for the 16 to 20 categories was 18 , at $24.35 \%$.

\subsection{The truthfulness and consistency of the questionnaire}

The stability of the questionnaire means that it is a stability in the scale used, that is, the scale will give the same results and with an equal probability to the value of the Cronbach's Alpha coefficient if it is reapplied to the same sample, as shown in Table No. (2) where we note that the value of the stability coefficient of electronic governance is 0.941 , that is, the stability The questions of this questionnaire are $94 \%$, and this is considered a positive indicator, as the number of questions in this questionnaire for e-governance is 15 questions. As for the dimensions of electronic governance, the stability was for e-governance 0.839 , transparency 0.771 , data generation 0.838 , and control 0.899 . 
While the stability factor of the intranet network was 0.748 , meaning that the stability of the questions of this questionnaire is $74 \%$, and this is considered a positive indicator.

Table 2. Results of the internal consistency test for the variables

\begin{tabular}{|c|c|c|c|}
\hline The scale & $\begin{array}{c}\text { Cronbach's Alpha } \\
\text { for axis }\end{array}$ & $\begin{array}{c}\text { No. of } \\
\text { Paragraphs }\end{array}$ & $\begin{array}{l}\text { Cronbach's Alpha } \\
\text { for all the axis }\end{array}$ \\
\hline \multicolumn{2}{|l|}{ e-government } & 15 & \multirow[t]{5}{*}{0.941} \\
\hline e-government & 0.839 & 3 & \\
\hline Transparency & 0.771 & 4 & \\
\hline Data generation & 0.838 & 4 & \\
\hline Control & 0.899 & 4 & \\
\hline \multicolumn{2}{|l|}{ Intranet } & 3 & 0.748 \\
\hline
\end{tabular}

This paragraph includes the description and diagnosis of the main study variables represented by the dimensions of electronic governance as an independent hub and the intranet as an approved axis in the institution. To achieve this, appropriate statistical analyzes were used.

Table 3. shows the weighted average and the direction of the answer

\begin{tabular}{|l|l|}
\hline \multicolumn{1}{|c|}{ The probably average } & The direction of the answer \\
\hline From 1 to 1.79 & Don't agree it sharply \\
\hline From 1.80 to 2.59 & Don't agree \\
\hline From 2.60 to 3.39 & Neutral \\
\hline From 3.40 to 4.19 & Agree \\
\hline From 4.20 to 5 & Agree symptom \\
\hline
\end{tabular}

Table No. (3) shows the direction of the answer to the questionnaire items according to the limits of the weighted average values.

Table No. 4. represents the sample description of the intranet hub and the e-governance hub

\begin{tabular}{|c|c|c|c|c|}
\hline paragraphs & $\begin{array}{l}\text { Standard } \\
\text { deviation }\end{array}$ & $\begin{array}{l}\text { Arithmetic } \\
\text { mean }\end{array}$ & $\begin{array}{c}\text { Relative } \\
\text { importance \% }\end{array}$ & $\begin{array}{l}\text { Answer } \\
\text { direction }\end{array}$ \\
\hline \multicolumn{5}{|c|}{ Intranet } \\
\hline $\begin{array}{l}\text { 1- The Intranet enables the institution to develop strategic } \\
\text { plans in giving the vision of implementing e-governance }\end{array}$ & 0.859 & 4.31 & 86.2 & $\begin{array}{c}\text { Agree } \\
\text { symptom }\end{array}$ \\
\hline $\begin{array}{l}\text { 2- The Ministry has a steering committee that oversees the } \\
\text { development and nurturing of the intranet network in }\end{array}$ & 1.089 & 3.86 & 77.2 & Agree \\
\hline \multirow[t]{2}{*}{$\begin{array}{l}\text { 3- The Ministry is monitoring the internal and external } \\
\text { environment to identify areas in which there is a need to adjust }\end{array}$} & 1.080 & 3.77 & 75.4 & Agree \\
\hline & 0.827 & 3.98 & 79.6 & Agree \\
\hline \multicolumn{5}{|c|}{ e-government } \\
\hline $\begin{array}{l}\text { 1- Our Ministry informs workers of all challenges and risks } \\
\text { facing the implementation of the Intranet regarding strategic }\end{array}$ & 1.154 & 3.89 & 77.8 & agree \\
\hline \multirow{3}{*}{$\begin{array}{l}\text { 2- Our ministry has indicators to monitor and evaluate the } \\
\text { weaknesses of the processor for implementing plans for e- } \\
\text { 3- Our ministry has a long-term plan to exercise the governing } \\
\text { procedures and create administrative leaders who are well }\end{array}$} & 0.975 & 3.81 & 76.2 & agree \\
\hline & 1.17 & 3.58 & 71.6 & agree \\
\hline & 0.959 & 3.76 & 75.2 & agree \\
\hline
\end{tabular}


Reflection Of The Use Of Intranet To Improve The Performance Of Electronic Governance An Exploratory Study Of The Ministry Of Higher Education And Al-Karkh Education Directorate

\begin{tabular}{|c|c|c|c|c|}
\hline $\begin{array}{l}\text { 1- Our ministry publishes information and data related to } \\
\text { future plans and projects }\end{array}$ & 1.103 & 3.65 & 73 & agree \\
\hline $\begin{array}{l}\text { 2- Electronic governance assists the ministry in providing } \\
\text { channels for disseminating information to help beneficiaries } \\
\text { gain access to them in a fair and transparent manner }\end{array}$ & 0.851 & 4.04 & 80.8 & agree \\
\hline $\begin{array}{l}\text { 3- The directors in the ministry implement all the criteria for } \\
\text { implementing governance }\end{array}$ & 1.137 & 3.46 & 69.2 & agree \\
\hline \multirow[t]{2}{*}{$\begin{array}{l}\text { 4- The rules governing electronic governance in the ministry } \\
\text { ensure that the information disclosed is based on high }\end{array}$} & 0.975 & 3.81 & 76.2 & agree \\
\hline & 0.788 & 3.74 & 74.8 & agree \\
\hline \multicolumn{5}{|c|}{ Data generation } \\
\hline $\begin{array}{l}\text { 1- The Ministry has information that facilitates the production } \\
\text { of data to receive decisions about planning and training to }\end{array}$ & 0.998 & 3.82 & 76.4 & agree \\
\hline $\begin{array}{l}\text { 2- Bottom-up information flow helps to formulate evidence- } \\
\text { haced noliciec in the annlication of anvernance }\end{array}$ & 0.818 & 4.04 & 80.8 & agree \\
\hline $\begin{array}{l}\text { 3- Our ministry has unified automated information in which } \\
\text { all information is presented within a clearlv defined svstem }\end{array}$ & 0.861 & 3.84 & 76.8 & agree \\
\hline \multirow[t]{2}{*}{$\begin{array}{l}\text { 4- Our ministry has the ability to analyze data that is obtained } \\
\text { through feedback }\end{array}$} & 1.094 & 3.62 & 72.4 & agree \\
\hline & 0.779 & 3.83 & 76.6 & agree \\
\hline \multicolumn{5}{|c|}{ Control } \\
\hline $\begin{array}{l}\text { 1- There are clear specific oversight instructions that allow for } \\
\text { control of governance implementation processes }\end{array}$ & 1.079 & 3.72 & 74.4 & agree \\
\hline $\begin{array}{l}\text { 2- Our ministry has a supervisory system that is fair, which } \\
\text { helps in proper application processes }\end{array}$ & 1.175 & 3.65 & 73 & agree \\
\hline $\begin{array}{l}\text { 3- Our ministry has special oversight to avoid risks in centers } \\
\text { where there are potential conflicts of interest }\end{array}$ & 1.097 & 3.69 & 73.8 & agree \\
\hline \multirow[t]{2}{*}{$\begin{array}{l}\text { 4- The supervisory system in our ministry controls ethical } \\
\text { behavior related to e-governance implementation processes }\end{array}$} & 1.136 & 3.68 & 73.6 & agree \\
\hline & 0.983 & 3.68 & 73.6 & agree \\
\hline
\end{tabular}

The results of the analysis of the respondents from the members of the sample for the axis of the intranet network in Table No. (4) indicate that the mean for the dimension of the intranet is (3.98) and that the standard deviation (0.827) while the relative importance was (79.6\%) where the answer direction is (Agreed), Since paragraph (1) was the most contributing to the enrichment of this dimension, as it obtained an arithmetic mean of (4.31) and a standard deviation of (0.859) with a relative importance of $(86 \%)$, where the answer was (I strongly agree). Table No. (4) indicated that the mean for data generation is the highest, where the mean was (3.83) and that the standard deviation for it is (0.779), while the relative importance is (76.6\%), as the direction of the answer is (Agreed), and the table indicates No. (4) also indicates that the mean of the transparency is (3.74) and that the standard deviation is (0.788) while the relative importance is (74.8\%) where the direction of the answer is (Agreed), as paragraph (2) was the most contributing In enriching this dimension, as I obtained an average mean of (4.04) and a standard deviation of (0.851) with a relative importance of (80.8\%). As Table No. (4) indicated that the mean of control is (3.68) and that the standard deviation for it is (0.983), while the relative importance is (73.6\%), as the direction of the answer is (Agreed), as paragraph (1) was It is the most contributing to enriching this dimension, as it obtained an arithmetic mean of (3.72) and a standard deviation of (1.079) with a relative importance of (74.4\%), as the direction of the answer is (Agreed).

\subsection{Hypotheses testing}

Main hypothesis test: which states that there is a significant effect of the intranet on the performance of electronic governance. 
Table 5. shows the explanatory power of the model

\begin{tabular}{|c|c|c|c|c|}
\hline \multicolumn{5}{|c|}{ Model Summary } \\
\hline Model & R & R Square & Adjusted R Square & Std. Error of the Estimate \\
\hline 1 & $.695^{\mathbf{a}}$ & .483 & .476 & .599 \\
\hline
\end{tabular}

a. Predictors: (Constant), e-government

Through table No. (5), we note that the value of correlation (R) was 0.483 , and the explanatory power of the model (R2) was 0.476 , meaning that the intranet network has interpreted $48.3 \%$ of the changes that occur in electronic governance.

Table 6.0 the effect of the intranet network on electronic governance

\begin{tabular}{|c|c|c|c|c|c|c|}
\hline \multicolumn{7}{|c|}{ Coefficients $^{\mathbf{a}}$} \\
\hline \multirow{2}{*}{\multicolumn{2}{|c|}{ Model }} & \multicolumn{2}{|c|}{ Unstandardized Coefficients } & \multirow{2}{*}{$\begin{array}{c}\text { Standardized Coefficients } \\
\text { Beta }\end{array}$} & \multirow[b]{2}{*}{$\mathbf{T}$} & \multirow[b]{2}{*}{ Sig. } \\
\hline & & $\mathbf{B}$ & Std. Error & & & \\
\hline 1 & (Constant) & 1.214 & .345 & - & 3.522 & .001 \\
\hline & Government & .737 & .090 & .695 & 8.200 & .000 \\
\hline
\end{tabular}

Table No. (6) indicates that the impact value reached $\mathrm{B}=(0.737)$, this means that increasing the intranet network by one unit of standard deviaions will lead to an increase in electronic governance by $73.7 \%$ of the unit of standard deviation.

Table 7. shows the choice of the coefficient of inflation and multiple linear regression

\begin{tabular}{|c|c|c|c|c|c|c|}
\hline \multicolumn{7}{|c|}{ Coefficients $^{\mathrm{a}}$} \\
\hline \multirow{2}{*}{\multicolumn{2}{|c|}{ Model }} & \multicolumn{2}{|c|}{ Unstandardized Coefficients } & \multirow{3}{*}{\begin{tabular}{|c} 
Standardized Coefficients \\
Beta \\
-
\end{tabular}} & \multirow{3}{*}{$\begin{array}{c}\mathrm{T} \\
\mathbf{3 . 5 2 9}\end{array}$} & \multirow{3}{*}{$\begin{array}{l}\text { Sig. } \\
.001\end{array}$} \\
\hline & & B & Std. Error & & & \\
\hline 1 & (Constant) & 1.146 & .325 & & & \\
\hline & e-government & .539 & .079 & .625 & 6.797 & .000 \\
\hline & Transparency & .627 & .099 & .597 & 6.313 & .000 \\
\hline & Data generation & .757 & .088 & .713 & 8.623 & .000 \\
\hline & Control & .463 & .083 & .551 & 5.603 & .000 \\
\hline
\end{tabular}

- Table No. (7) indicates the significance of the effect of the e-governance administration, because the value of Sig. It is equal to 0.000 and is less than 0.05 , and this indicates the fulfillment of the first sub hypothesis.

- Table No. (7) indicates the significance of the effect of e-governance, because the value of Sig. Equal to 0,000 and less than 0.05 , this indicates the fulfillment of the second sub-hypothesis.

- Table No. (7) indicates the significance of the transparency effect, because the value of Sig. It is equal to 0.000 which is less than 0.05 , and the effect value $(\mathrm{B}=0.62)$ ) that is, increasing the transparency variable and one unit of standard deviations will lead to an increase in electronic governance by $62.7 \%$ of the unit of standard deviation.

- Table (7) indicates the significance of the effect of data generation, because the value of Sig. It is equal to 0.000 which is less than 0.05 , and the effect value $(B=0.757)$ that is, the increase in the data generation variable for one unit of standard deviations will lead to an increase in electronic governance by $75.7 \%$ of the unit of standard deviation. - Table No. (7) indicates the significance of the control effect, because the value of Sig. It is equal to 0.000 which is less than 0.05 , and the effect value $(B=0.463)$ that is, increasing the control variable and one unit of standard deviations will lead to an increase in electronic governance by $46.3 \%$ of the unit of standard deviation.

Table 8. shows the analysis of variance

\begin{tabular}{|c|c|c|c|c|c|c|}
\hline \multicolumn{7}{|c|}{ ANOVA $^{a}$} \\
\hline \multicolumn{2}{|c|}{ Model } & Sum of Squares & Df & Mean Square & $\mathbf{F}$ & Sig. \\
\hline \multirow[t]{3}{*}{1} & Regression & 24.133 & 1 & 24.133 & 67.234 & $.000^{b}$ \\
\hline & Residual & 25.843 & 72 & .359 & - & - \\
\hline & Total & 49.976 & 73 & - & - & - \\
\hline
\end{tabular}

The results of the F test in Table No.(8) indicate that there is a correlation to the dimensions of the intranet network to improve the performance of electronic governance, and that the calculated value of $F$ has reached (67.234) at the level of significance (0.05) where the value of P-value is equal to (0.000) which is less than 0.05 . 
Reflection Of The Use Of Intranet To Improve The Performance Of Electronic Governance An Exploratory Study Of The Ministry Of Higher Education And Al-Karkh Education Directorate

Table 9. the effect of intranet on improving the performance of electronic e-governance

\begin{tabular}{|c|c|c|c|c|}
\hline \multirow{2}{*}{$\begin{array}{r}\begin{array}{r}\text { Supported } \\
\text { variable }\end{array} \\
\begin{array}{c}\text { Dependent } \\
\text { variable }\end{array} \\
\end{array}$} & \multicolumn{4}{|c|}{ Intranet } \\
\hline & $\mathbf{F}$ & $\mathbf{R}^{2}$ & B & Slow signal \\
\hline e-government & 46.197 & 0.391 & 1.955 & moral \\
\hline Transparency & 39.855 & 0.356 & 1.637 & moral \\
\hline Data generation & 74.363 & 0.508 & 1.080 & moral \\
\hline Control & 31.388 & 0.304 & 2.276 & moral \\
\hline
\end{tabular}

Table No. (9) indicates that the value of R2 is equal to (0.391), which means that electronic governance has interpreted a rate of $(39 \%)$ of changes in the intranet, and the value of $(\mathrm{B}=1.955)$ that is, that the increase in the e-governance variable is a unit one of the standard deviations will lead to the efficiency of the intranet network by $19.55 \%$ of the standard deviation unit. mTable No. (9) indicates that the value of R2 is equal to (0.356), and this means that transparency has explained (35.6\%) of the changes that occur in improving the intranet network and the value of $\mathrm{B}=$ 1.637) (that is, the increase in the transparency variable is a unit One of the standard deviations will increase the intranet by $16.37 \%$ from the standard deviation unit. Table No. (9) indicates that the value of R2 is equal to (0.508), and this means that data generation has explained (50.8\%) of the changes that occur on the intranet, and the value of $(\mathrm{B}=1.080)$ that is, the increase in the data generation variable one unit of standard deviation will increase the intranet by $10.8 \%$ of the unit of standard deviation. Table No. (9) indicates that the value of R2 is equal to (0.304), and this means that the control has interpreted a rate of (30.4\%) of the changes that occur on the intranet network and the value of $(\mathrm{B}=2.276)$ has reached that is, the increase in the control variable is one unit of Standard deviations will increase the intranet by $22.76 \%$ from the standard deviation unit.

\section{Conclusions and Recommendations} Explanatory results:

1. Table No. 1 indicates that the percentage of females in the researched organization is $(47.3 \%)$, while the males were $(52.7 \%)$, which is an equal proportion for the researched organization.

2. The results indicate through Table No. (4) that electronic governance has obtained a general arithmetic mean of (3.76) and a standard deviation (0.959), which indicates the homogeneity of the study sample answers about the value of the arithmetic mean.

a. As for the level of its dimensions, it came after the generation of data, as it was more homogeneous in terms of staff answers, and the direction of this dimension is (Agreed).

b. As for the level of the paragraphs, paragraph (2) came in this dimension (e-governance helps the ministry in providing channels for disseminating information to help the beneficiaries gain access to them in a fair and transparent manner), it is the most homogeneous, that the direction of this paragraph is (Agreed).

c. On the level of the transparency dimension, the answers of the employees and the direction of this dimension was (Agreed).

h. As for axis monitoring, I got a general mean of (3.68) and a standard deviation (0.983), which indicates the homogeneity of the study sample answers about the value of the mean.

3. Through table (6) there is a significant relationship between the intranet network and electronic governance where the value of the correlation coefficient Pearson was significant and equal to 0.737 , because the moral value of sig equals 0.000 which is less than 0.05 which indicates the achievement of the first main hypothesis. As for the sub-hypotheses, it was a significant relationship between:

a. Transparency and electronic governance. The value of the relationship was (0.627).

b. Data generation and electronic governance. The value of relationship was $(0.757)$.

c. E-Governance and Control The relationship value was (0.463).

\section{This means accepting the hypotheses (first, second and third).}

4. Table (8) indicates that the results of the test $(F)$ indicate the existence of a link to the dimensions of electronic governance because the calculated value of $F$ reached (67.234) at a significant level (0.05) which is greater than its tabular top, the value of $\mathrm{P}$ is equal to (0.000) which is less than (0.05) This means accepting the alternative hypothesis 
and rejecting the null hypothesis, and this means (there is an effect of the intranet on improving the performance of electronic governance).

5. From the results of Table (9), it is found that the value of (R2) equals (0.39), which indicates that the trend of electronic governance has interpreted $39 \%$ of the changes that occur in electronic governance.

6. There is a significant effect of transparency on governance because the value of (R2) equals $(0.356)$, where he explained $(35.6 \%)$ of the changes that occur in governance.

7. There is a significant effect of data generation on electronic governance because the value of (R2) equals (0.508), where he explained $(50.8 \%)$ of the changes that occur to the government.

8. The presence of a significant effect of the control on governance, because the value of (R2) equals (0.304), and he explained $(30.4 \%)$ of the changes that occur in the governance.

Theoretical results:

1- There is an interconnectedness and compatibility between the intranet and electronic governance.

2- Institutions' dependence on strategic direction as a distinctive character of their future strategic direction.

3 - The university's pursuit of technological developments and the pursuit of its investment makes decision-makers at the university examine the environment and research its components and try to pair with it and make an assessment of its nature.

4- The university's endeavor to adopt modern systems for information and communication technology systems within the framework of governance is in order to provide sufficient information as inputs to the strategic direction process within the indicators and principles of transparency, oversight and accountability.

\section{Recommendations:}

1. The necessity of focusing on increasing the percentage of females in the top management of the researched organization.

2. Work to increase the level of the electronic examination of the network and conduct more analyzes of the components of electronic governance in order to achieve the maximum levels of pairing with variables and dimensions, and then seek to include these procedures in the evaluation process and take appropriate decisions and benefit from that in the future.

3. The need to increase attention to its highest levels through the adoption of several methods, perhaps the most prominent of which are the mission, strategic goals and strategic vision and its impact on the application of electronic governance.

4. The necessity of developing and using information and communication technology systems on an ongoing basis, providing them with the required quality, and presenting them to the institution's customers in a manner that is commensurate with their capabilities.

5. Implementing training courses and workshops to perpetuate the culture of electronic governance within the institution for the purpose of keeping pace with recent developments, which:

- Spreading awareness of the importance of implementing e-governance through its principles and emphasizing the increase in the principles of transparency and information generation.

- Focusing on the issue of electronic governance and trying to establish this concept by enhancing its culture and raising the level of understanding and awareness of its importance as a remedy to fight corruption and raise performance, as managers and workers should be educated and trained in governance issues.

6. Expanding and developing the infrastructure so that it can be compatible with the technological development and services for the application of electronic governance.

\section{References}

1. James F. Kurose, Keith W. Ross, "Computer and Internet Networks Bases and Principles of Networks”, AlAayan Publishing House, Saudi Arabia

2. Zaher Hashem, 2018, "What is a local area network (LAN)", Zad School, Saudi Arabia, pp. 23.

3. Al-Balawi, Mohammed bin Ahmed Salem, 2019, "Strategic Awareness and Governance", the second international arbitration conference, Al-Warraq Publishing, Oman, pp. 44.

4. Osama Abdel Moneim, Omar Iqbal Al-Mashhadani, 2019, "Strategic Awareness and Governance", the second international arbitration conference, Al-Warraq Publishing, Oman.

5. Hamza, Tahani Al-Rasheed Ahmed, 2015, "Strategic direction and its impact on communication companies, knowledge management as an intermediate variable," unpublished PhD thesis, Sudan University of Science and Technology, Sudan.

6. Auh, S., \& Mengue, B., 2018, "the influence of top management team", International Journal of Research in Marketing, Vol. 22, No 1.

7. Agnagiba W., 2016, "E-governance justified", (IJACSA) International Journal of Advanced Computer Science and Applications, Vol. 4, No. 2.

8. Budd, L., Harris, L. (red), 2019, “E-governance: managing or governing”, New York, NY: Routledge. 
Reflection Of The Use Of Intranet To Improve The Performance Of Electronic Governance An Exploratory Study Of The Ministry Of Higher Education And Al-Karkh Education Directorate

9. O. V. Bondarenko, O. V. Pakhomova, and V. I. J. a. p. a. Zaselskiy, "The use of cloud technologies when studying geography by higher school students," 2019.

10. Margaret Rouse, "Computer hardware", search networking, tech target.com, 2019.

11. Rashid, Ibrahim, 2018, "Corporate Governance and its Financial Implications for Banks", Faculty of Administration and Economics, Al-Mustansiriya University.

12. Shalaby, Sabry Ahmed, 2013, "The Role of Governance in Administrative Reform", Master Thesis, Arab Academy Denmark, Faculty of Law and Politics.

13. J. P. Rossing, W. Miller, A. K. Cecil, and S. E. Stamper, "iLearning: The future of higher education? Student perceptions on learning with mobile tablets," 2012.

14. J. A. Bowen, Teaching naked: How moving technology out of your college classroom will improve student learning. John Wiley \& Sons, 2012.

15. A. H. Alaidi, O. Yahya, and H. T. S. J. I. J. o. I. M. T. Alrikabi, "Using Modern Education Technique in Wasit University," vol. 14, no. 06, pp. 82-94, 2020.

16. W. J. H. E. Ali, "Online and Remote Learning in Higher Education Institutes: A Necessity in light of COVID19 Pandemic," vol. 10, no. 3, 2020.

17. [N. S. Alseelawi, E. K. Adnan, H. T. Hazim, H. T. S. ALRikabi, and K. W. J. I. J. o. I. M. T. Nasser, "Design and Implementation of an E-learning Platform Using N-Tier Architecture," vol. 14, no. 06, pp. 171-185, 2020.

18. N. S. AbdulRazak, M. A. J. E. Ali, and T. Journal, "Challenges of Implementation E-Learning Platforms in Iraqi Universities," vol. 37, no. 4 C, pp. 400-406, 2019.

19. H. T. S. ALRikabi, A. H. M. Alaidi, F. T. J. J. o. A. R. i. D. Abed, and C. Systems, "Attendance System Design And Implementation Based On Radio Frequency Identification (RFID) And Arduino," vol. 10, no. 4, p. 6, 2018.

20. A. Al-Azawei, P. Parslow, K. J. T. I. R. o. R. i. O. Lundqvist, and D. Learning, "Barriers and opportunities of e-learning implementation in Iraq: A case of public universities," vol. 17, no. 5, 2016.

21. A. S. Elameer and R. M. Idrus, "Modified Khan eLearning Framework for the Iraqi Higher Education," in The Seventh International Conference on eLearning for Knowledge-Based Society, 2010, pp. 16-17.

22. H. T. Alrikabi, A. H. M. Alaidi, A. S. Abdalrada, and F. T. J. I. J. o. E. T. i. L. Abed, "Analysis the Efficient Energy Prediction for 5G Wireless Communication Technologies," vol. 14, no. 08, pp. 23-37, 2019.

23. S. R. Malikowski, M. E. Thompson, and J. G. J. J. o. e. c. r. Theis, "A model for research into course management systems: Bridging technology and learning theory," vol. 36, no. 2, pp. 149-173, 2007.

24. N. A. Hussien, I. K. Ajlan, M. F. M. Firdhous, and H. T. S. J. I. J. o. I. M. T. Alrikabi, "Smart Shopping System with RFID Technology Based on Internet of Things," vol. 14, no. 04, pp. 17-29, 2020.

25. S. A. Becker, M. Cummins, A. Davis, A. Freeman, C. G. Hall, and V. Ananthanarayanan, "NMC horizon report: 2017 higher education edition," The New Media Consortium2017.

26. Y. Mahdavinasab, E. Sadipour, and M. J. Q. J. o. I. D. E. Moradi, "An Investigation of the Effective Components Considered in Designing E-Learning Environments in Higher Education and Offering a Framework for E-Learning Instructional Design," vol. 1, no. 4, pp. 9-24, 2019.

27. M. J. J. Bossetta and m. c. quarterly, "The digital architectures of social media: Comparing political campaigning on Facebook, Twitter, Instagram, and Snapchat in the 2016 US election," vol. 95, no. 2, pp. 471-496, 2018.

28. Hussain Hamed Khdair Jinah. He is an employee of the General Directorate of Education in Baghdad, the third Karkh Governorate, responsible for the Division of Educational Research and Studies, Baghdad, Iraq. Bachelor of Computer Science and Information Technology from University of Baghdad.

29. Master's degree from Saratov State University of Research, Russia.

30. Email: hussein.h.k1984@gmail.com

31. The number of articles in international databases -1 .

32. (2) Duha Khalid Abdul-Rahman Al-Malah, she is a Lecturer. She is the reporter department of Tourism and Hotel Management, Responsible of the Central Library Division, Instructor for Calculator Applications Course in Administrative Technical College, Northern Technical University, Mosul, Iraq.

33. Bachelor of Computer Science, Mosul, Iraq.

34. Higher diploma in computers, E-learning and education, Baghdad, Iraq.

35. E-mail: duhakm@ntu.edu.iq.

36. The number of articles in national databases -6 ,

37. The number of articles in international databases -3 . 
38. (3) Raed Sami Sarhan he is an assistant teacher at the General Directorate of Education in Baghdad, The Third Karkh Governorate, director of the High School for Excellence, Baghdad, Iraq. Bachelor of Computer Science, University of Baghdad,

39. Master's degree of Information Systems from AL- Mansoura University - Egypt

40. Email: Raidsami28@gmail.com

41. The number of articles in international of databases -2 